\title{
Historic nitrogen deposition determines future climate change effects on nitrogen retention in temperate forests
}

\author{
T. Dirnböck ${ }^{1}$ (D) - C. Foldal ${ }^{2} \cdot$ I. Djukic $^{1} \cdot$ J. Kobler $^{1}$ • \\ E. Haas ${ }^{3} \cdot$ R. Kiese ${ }^{3}$ - B. Kitzler ${ }^{2}$
}

Received: 2 December 2016 / Accepted: 4 July 2017 / Published online: 21 July 2017

(C) The Author(s) 2017. This article is an open access publication

\begin{abstract}
Nitrogen (N) cycle processes in terrestrial ecosystems are highly sensitive to temperature and soil moisture variations. Thus, future climate change may affect the degree to which $\mathrm{N}$ deposited from the atmosphere will be retained in forest ecosystems. We evaluated the effect of future changes in climate and $\mathrm{N}$ deposition on ecosystem $\mathrm{N}$ cycling using the model LandscapeDNDC forced with historical data from eight long-term forest ecosystem monitoring stations in Austria and downscaled future $\mathrm{N}$ deposition and climate scenarios. With every $1{ }^{\circ} \mathrm{C}$ of warming, annual $\mathrm{N}$ uptake in biomass increased by +0.03 to $+0.54 \mathrm{~kg} \mathrm{~N} \mathrm{ha}^{-1}$, total soil organic matter (SOM) increased annually by +0.003 to $+0.08 \mathrm{~kg} \mathrm{~N}^{-1}$, and mean annual $\mathrm{N}$ leaching was between -0.09 and $-2.03 \mathrm{~kg} \mathrm{~N}^{-1}$ lower. The magnitude of $\mathrm{N}$ deposition in the years from 1990 to 2010 was by far the most important determinant of the response of nitrogen cycling to future warming, including statistically significant relationships with humus $\mathrm{N}$ content and $\mathrm{N}$ leaching. We conclude that climate change will likely increase ecosystem $\mathrm{N}$ retention in temperate forest ecosystems, and even more so at forest sites with high past $\mathrm{N}$ deposition.
\end{abstract}

Electronic supplementary material The online version of this article (doi:10.1007/s10584-017-2024-y) contains supplementary material, which is available to authorized users.

T. Dirnböck

thomas.dirnboeck@umweltbundesamt.at

1 Department for Ecosystem Research and Environmental Information Management, Environment Agency Austria, Spittelauer Lände 5, A-1090 Vienna, Austria

2 Austrian Research Centre for Forests BFW, A-1131 Vienna, Austria

3 Karlsruhe Institute of Technology, Institute of Meteorology and Climate Research, Atmospheric Environmental Research (IMK-IFU), Kreuzeckbahnstraße 19, 82467 Garmisch-Partenkirchen, Germany 


\section{Introduction}

Nitrogen deposition has led to changes in carbon and nitrogen dynamics in forest ecosystems (Butterbach-Bahl and Gundersen 2011), causing changes in $\mathrm{C}$ sequestration (Thomas et al. 2010; Yue et al. 2016), increased nitrate leaching (Gundersen et al. 2006), increased gaseous N emissions (van Groenigen et al. 2015) and the loss of plant species susceptible to high nutrient availability (Dirnböck et al. 2014). N deposition effects are predominantly discussed in the conceptual framework of ecosystem $\mathrm{N}$ saturation where an oversupply of $\mathrm{N}$ is thought to gradually diminish $\mathrm{N}$ retention, and surplus $\mathrm{N}$ leaves the ecosystem via leaching or gaseous emissions (Aber et al. 1998; Lovett and Goodale 2011).

A variety of factors affect N cycling in terrestrial ecosystems. Soil organic matter (SOM) decomposition is temperature sensitive (Davidson and Janssens 2006) and soil warming leads to enhanced $\mathrm{N}$ mineralization and nitrification (Butler et al. 2012), though the latter strongly depends also upon the availability of $\mathrm{NH}_{4}{ }^{+}$(Butterbach-Bahl and Gundersen 2011). Furthermore, soil water content affects the temperature sensitivity of SOM decomposition (Davidson and Janssens 2006) and controls gaseous $\mathrm{N}$ efflux (Butterbach-Bahl et al. 2013). In addition to climatic conditions, $\mathrm{N}$ processes depend to a large extent upon soil characteristics, management and vegetation type. Soil properties such as soil texture and porosity can affect $\mathrm{N}$ turnover in soils, via their impacts on soil hydrology, $\mathrm{N}$ adsorption and soil organic carbon concentrations (Butterbach-Bahl and Gundersen 2011). Low topsoil C:N ratios $(<20-25)$ have been shown to indicate increased nitrate leaching and gaseous N loss (Gundersen et al. 2006). Apart from the $\mathrm{N}$ losses the $\mathrm{C}: \mathrm{N}$ ratio also relates to $\mathrm{N}$ availability because $\mathrm{N}$ immobilisation dominates at high $\mathrm{C}: \mathrm{N}$ ratios while net mineralisation increases and net nitrification occurs at low C:N ratios (Aber et al. 2003; Dannenmann et al. 2007). Soil acidity also controls N transformation by generally reducing the abundance and activity of fine roots and microorganisms (Brumme and Khanna 2008). Vegetation type has major effects on ecosystem $\mathrm{N}$ cycling controlling litter quality, root distribution and canopy structure that affect soil moisture, temperature and substrate availability, microbial $\mathrm{N}$ turnover as well as nitrate leaching and gaseous N loss (Brumme et al. 1999; Butterbach-Bahl et al. 2002; Rothe et al. 2002).

$\mathrm{N}$ uptake by trees is sensitive to climate change because tree growth is related to temperature. Enhanced tree growth has been observed during the last decades (Fang et al. 2014; McMahon et al. 2010; Pretzsch et al. 2014a; Pretzsch et al. 2014b). Warming can increase tree growth directly or via the enhancement of $\mathrm{N}$ availability by increasing rates of $\mathrm{N}$ mineralization and nitrification (Butler et al. 2012). Enhanced tree growth can cause soil nutrient depletion (N, phosphor and base cations) rendering limitations in tree growth (Jonard et al. 2015; Templer 2013). Increasing drought conditions may also counteract growth acceleration that is caused by warming (Charru et al. 2014).

Though combined effects of $\mathrm{N}$ deposition and climate change are studied more often, so far it still remains elusive as to how forest ecosystem $\mathrm{N}$ retention might be affected in future (Porter et al. 2013). Here, we use data from eight long-term forest ecosystem monitoring stations in Austria with different $\mathrm{N}$ status to calibrate a physiologically oriented ecosystem model (LandscapeDNDC) with a detailed soil process description (Haas et al. 2013; MolinaHerrera et al. 2015). We hypothesise that in temperate forest ecosystems, climate warming will increase tree growth and will enhance $\mathrm{N}$ mineralization and nitrification. In sum, climate change will compensate $\mathrm{N}$ saturation by increasing $\mathrm{N}$ retention, resulting into less $\mathrm{N}$ leaching and gaseous losses. The temporal dynamics and magnitude of this 
offsetting process will strongly depend upon site conditions, but also on historic and future $\mathrm{N}$ deposition and climate change trajectories.

\section{Methods}

\subsection{Site description}

We used eight long-term forest monitoring and research sites (Table 1) spanning altitudinal ranges between lowland (290 m a.s.1.) and montane to subalpine areas (1540 m a.s.1.). Mean annual temperature $(\mathrm{T})$ variation is mostly related to this altitudinal gradient and ranges between 4.2 and $10.8{ }^{\circ} \mathrm{C}$ with a pronounced seasonal pattern typical for temperate forest ecosystems. Lowland sites in eastern Austria experience the lowest mean annual precipitation $\left(600-700 \mathrm{~mm} \mathrm{y}^{-1}\right)$ whereas sites in the Northern Limestone Alps receive around $1500 \mathrm{~mm} \mathrm{y}^{-1}$. $\mathrm{N}$ deposition is highest at sites with high precipitation (15-28 $\left.\mathrm{kg} \mathrm{N} \mathrm{ha}^{-1} \mathrm{y}^{-1}\right)$ and at sites in eastern Austria (12-18 $\mathrm{kg} \mathrm{N} \mathrm{ha}^{-1} \mathrm{y}^{-1}$ ). Norway spruce (Picea abies (L.) H. Karst.) is the dominant tree species except at two sites where either European beech (Fagus sylvatica L.) (KL09) or oak species (Quercus petraea Liebl., Qu. cerris L.) (UP02) dominate. The soils range from acidic $(\mathrm{pH}<4)$ to neutral $(\mathrm{pH} \mathrm{6-7)}$. Three sites have carbonate bedrock with high soil $\mathrm{pH}$ and base saturation (AK22, MG15 and ZB00). Whereas AK22 and ZB00 has mull type humus characterized by low C:N ratios of 16.8-17.0, MG15 has a moder type humus with a C:N ratio of 25.6. Three sites, JO17, KL09 and UP02, have acidic soils (pH 3.9-4.6), high base saturation (70-90\%) and similar A-horizon C:N ratios (12.8-13.9). JO17 has a mixed moder-mull humus type, KL09 and UP02 had a mull humus. Two sites are characterised by very acidic soils ( $\mathrm{pH} 3.6-3.7)$, low base saturation, moder type humus with $\mathrm{C}: \mathrm{N}$ ratios of 20.4 and 23.7 (Table 1).

\subsection{LandscapeDNDC model}

LandscapeDNDC is a modular ecosystem model that combines detailed soil $\mathrm{C}, \mathrm{N}$ and water process representations with physiologically oriented vegetation descriptions. It is designed for simulating ecosystem $\mathrm{C}$ and $\mathrm{N}$ turnover and losses including associated changes in the $\mathrm{C}$ and $\mathrm{N}$ stocks of soils (Haas et al. 2013). A particularly strong part of the model is the detailed description of ecosystem nitrogen processes, including trace gas emission and leaching. Generally process descriptions are based on Li et al. (1992) and Li et al. 2000). LandscapeDNDC was evaluated to represent the water, $\mathrm{C}$ and $\mathrm{N}$ cycling of various forest ecosystems under different weather and soil conditions (Holst et al. 2010; Molina-Herrera et al. 2015) and used successfully to simulate nitrate leaching for one of the forest sites (Dirnböck et al. 2016). For the current analysis, we used a more detailed forest growth model within LandscapeDNDC (Grote et al. 2011a; Grote et al. 2011b; Grote et al. 2009).

\subsection{Input data}

LandscapeDNDC was initialized using site-specific information on longitude, latitude, annual precipitation, slope, aspect and vertically distributed physical and chemical soil properties and profile information: soil texture, soil organic carbon and nitrogen, bulk density, saturated hydraulic conductivity, stone fraction, $\mathrm{pH}$, field capacity and wilting 


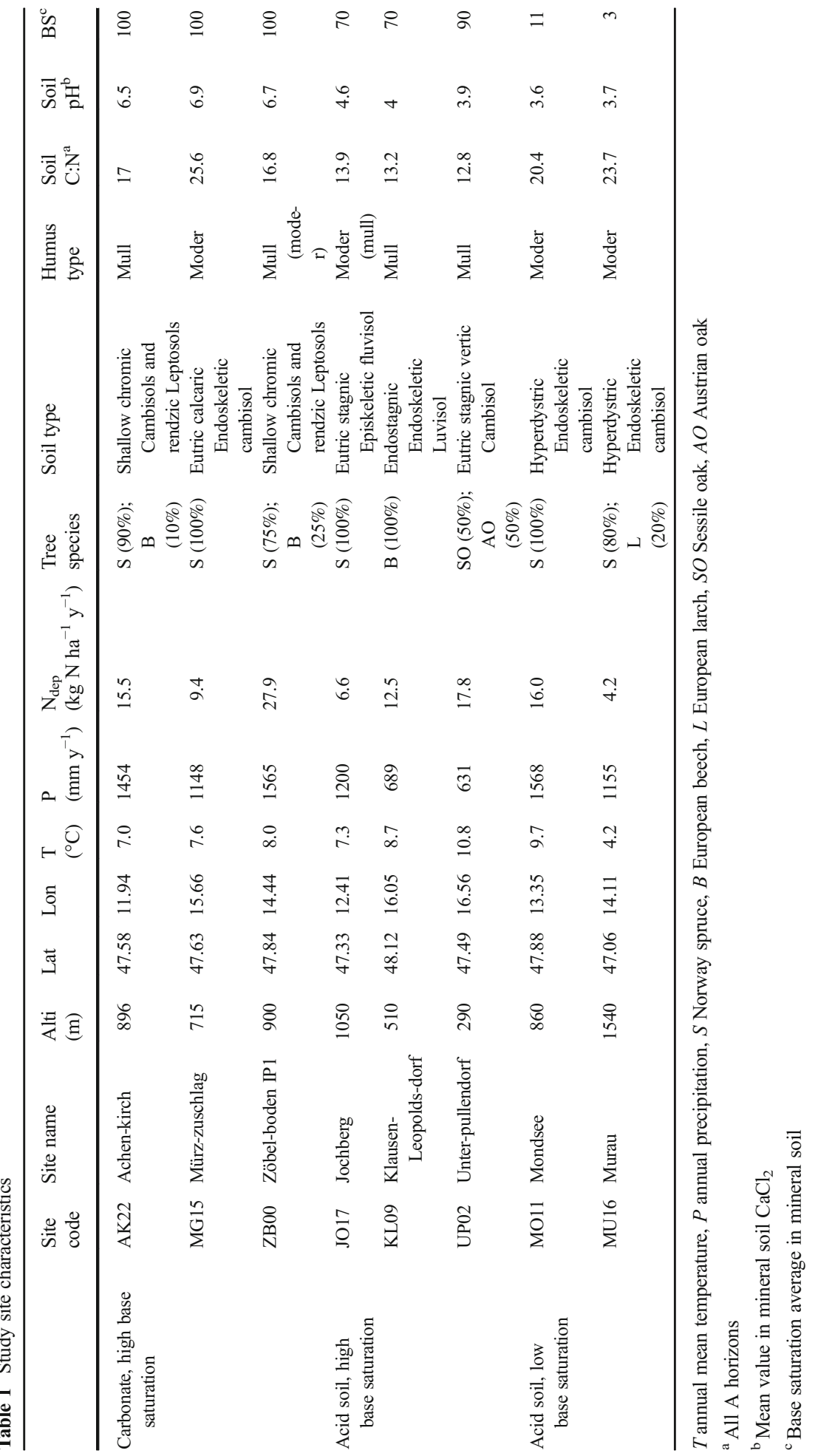


point. For the sites simulated, soil input data was taken from Mutsch et al. (2013) and Dirnböck et al. (2016). LandscapeDNDC uses daily climate data of air temperature, precipitation, solar radiation, $\mathrm{N}$ deposition and atmospheric $\mathrm{CO}_{2}$ concentration. Since the focus of this study was to disentangle climate effects on $\mathrm{N}$ cycling, we kept $\mathrm{CO}_{2}$ concentrations constant at the value of the year 2000 (370 ppm). Soil moisture in 15 and $30 \mathrm{~cm}$ soil depth was used for model evaluation.

Tree species-specific volume, height and diameter for the entire rotation period were taken from species-specific yield tables (Marschall 2011) taking into account the site-specific yield classes that were defined by using tree age and maximum tree height from the years 1995, 2000, 2005 and 2009. To ensure comparability among sites, simulations were based on forest plantation in 1950, a spin up time of 40 years (until 1990), and covered a simulation period of 110 years (1990-2100). Tree harvest was defined according to common procedures without implementing a clear-cut.

By using the weather generator ClimGen (Stöckle et al. 1999) and measured data (2027 years, see S1), we derived the baseline climate time series for 1950-2100. Then, scenario data were synthesized by means of anomalies gathered from the A1B, A2 and B1 scenarios (IPCC AR4 WG1 2007). Parameter-specific monthly climate change anomalies for each of the study sites were derived from the respective grid cell of the regional climate model COSMOCLM (Loibl et al. 2011). The A1B, A2, and B1 scenarios were based on the global circulation model ECHAM5, and the A1B scenario was also available from the HadCM3 model (see S1 $\mathrm{T} 1$ for differences between scenarios). We ran LandscapeDNDC with each of these scenarios and the results, if not mentioned otherwise, are presented as averages over scenarios.

Daily total dry and wet $\mathrm{N}$ deposition for 1950-2100 was derived from retrospective modelling and considered three future scenarios: the current legislation (CLE) scenario with revised Gothenburg Protocol emissions and the technically maximum feasible emission reduction scenario (MFR). CLE and MFR scenarios assume no change in deposition after 2030. A baseline scenario was defined by the 2010 deposition values with no further reductions (B10) (see S1 for more details).

\subsection{Model optimization}

According to Molina-Herrera et al. (2015), we optimized for each site three forest structure development and growth parameters: HDMAX which regulates the height diameter ratio for mature trees in dense stands, HREF which defines the canopy depth where full foliage is developed and the KM20 maintenance respiration coefficient at reference temperature following (Thornley and Cannell 2000). The optimization was based on a Markov Chain Monte Carlo calibration minimizing the Euclidian distance (Molina-Herrera et al. 2015) between simulation results for tree volume, height and diameter and every 20-30 year values according to the yield tables. The optimization routine performed several thousand site simulations for 150 years for each parameter. Parameter ranges were defined a priori for each species based on literature data (Molina-Herrera et al. 2015). The calibration was performed for all sites independently.

\subsection{Data analysis and statistics}

By following Lovett and Goodale (2011), we focused on the temporal dynamics of $\mathrm{N}$ in plant biomass, $\mathrm{N}$ in the forest floor (humus $\mathrm{N}$ ), $\mathrm{N}$ in the mineral soil, soil $\mathrm{N}$ loss via gaseous 
emissions $\left(\mathrm{N}_{2} \mathrm{O}, \mathrm{N}_{2}\right.$ and $\left.\mathrm{NO}\right)$ and via leaching in seepage water $\left(\mathrm{NO}_{3}{ }^{-}\right.$and $\left.\mathrm{NH}_{4}{ }^{+}\right)$. First, we characterised the current state and direction of $\mathrm{N}$ fates by calculating mean annual vegetation and soil pools and fluxes of the period 1990-2010. Differences in the fluxes between sites were tested separately for each group with a non-parametric Kruskal-Wallis test. Second, we inferred whether the sites accumulated or lost SOM N under the different combinations of climate and $\mathrm{N}$ deposition scenarios ( $n=15$ for each site). For this, we tested if simulated annual changes in humus $\mathrm{N}$, mineral soil $\mathrm{N}$ and the sum of both (total SOM N) were different from zero during the period 2010-2100 with a Wilcoxon rank sum test. And third, we quantified effects of $\mathrm{N}$ deposition and climate on all $\mathrm{N}$ fates for each site by comparing mean $\mathrm{N}$ pools and mean annual $\mathrm{N}$ fluxes of all combinations of scenarios ( $n=15$ for each site) considering time periods of 1990-2010 and 2080-2100, respectively, assuming that differences between the two time periods are representative for changes in $\mathrm{N}$ fates. In order to separate $\mathrm{N}$ deposition and climate effects on $\mathrm{N}$ fates, we used the baseline climate scenario and the MFR N deposition (the lowest $\mathrm{N}$ deposition) scenario as a reference. We subtracted the changes in mean annual $\mathrm{N}$ increments resulting under the MFR N deposition scenario from those derived under the B10 and CLE N deposition scenarios (and all climate scenarios), and we subtracted the $\mathrm{N}$ changes resulting under the A1B, A2 and B1 climate scenario from those derived under the baseline climate scenarios (and all $\mathrm{N}$ deposition scenarios). Whether these effects were significantly different from zero was tested with a Wilcox rank sum test. In order to compare sites, we also calculated these effects per $1 \mathrm{~kg} \mathrm{~N}$ deposition and per $1{ }^{\circ} \mathrm{C}$ warming by dividing changes of $\mathrm{N}$ fates with changes in $\mathrm{N}$ deposition and temperature, respectively, and tested differences between sites with a post-hoc multi-comparison Nemeneyi test (Pohlert 2014). Whether these standardized effects on $\mathrm{N}$ fates were related to past $\mathrm{N}$ deposition, climate (means between 1990 and 2010), soil pHvalues and A-horizon C:N ratios (measurements between 2005 and 2007), were tested with linear least square regression.

\section{Results}

\subsection{Current (1990-2010) N status of the study sites}

Among the sites with carbonate bedrock, simulated N stored in trees between 1990 and 2010 was 1.5 and 1.9-fold higher in ZB00 than in AK22 and MG15, respectively. The SOM N pool was 2.6-2.7-fold in AK22 than ZB00 and MG15 (Table 2). N loss via leaching $\left(\mathrm{NO}_{3}{ }^{-}+\mathrm{NH}_{4}{ }^{+}\right)$ and in gaseous $\left(\mathrm{N}_{2} \mathrm{O}, \mathrm{N}_{2}\right.$ and $\mathrm{NO}$ ) form was 15.1 and $3.4 \mathrm{~kg} \mathrm{~N} \mathrm{ha}^{-1} \mathrm{y}^{-1}$ at $\mathrm{ZB00}$, summing up to $68 \%$ of the $\mathrm{N}$ deposition (54\% leaching, $14 \%$ gaseous). MG15 lost $3.7 \mathrm{~kg} \mathrm{~N} \mathrm{ha}^{-1} \mathrm{y}^{-1}$ via gaseous efflux (39\% of $\mathrm{N}$ deposition) and $1 \mathrm{~kg} \mathrm{~N}$ ha $^{-1} \mathrm{y}^{-1}$ via $\mathrm{N}$ leaching (11\%). $\mathrm{N}$ loss via leaching was $3.6 \mathrm{~kg} \mathrm{~N}^{-1} \mathrm{y}^{-1}$ (32\% of $\mathrm{N}$ deposition) and gaseous $\mathrm{N}$ efflux was $1.4 \mathrm{~kg} \mathrm{~N} \mathrm{ha}{ }^{-1} \mathrm{y}^{-1}$ in AK22 (23\% leaching, 9\% gaseous) (Table 2, S2 F1). Annual N fluxes between 1990 and 2010 were different between the sites (Kruskal-Wallis $X^{2}=39.2-52.5$, df $=2, p<0.001)$.

At sites with acidic soils and high base saturation, the amount of simulated $\mathrm{N}$ stored in the trees between 1990 and 2010 was 1.7 and 1.3-fold in KL09 than in JO17 and UP02, respectively. Though these three sites had similar mineral soil $\mathrm{N}$ pools $\left(6405-8821 \mathrm{~kg} \mathrm{~N} \mathrm{ha}^{-1}\right)$ in the period 1990-2010, humus N pool was 1.8 and 1.5-fold in JO17 than in KL09 and UP02, respectively (Table 2). Simulated N leaching was $<2 \%$ of N deposition at JO17 and KL09 but was $5.6 \mathrm{~kg} \mathrm{~N} h a^{-1} \mathrm{y}^{-1}$ at UP02 (31\% of $\mathrm{N}$ deposition). In JO17, simulated gaseous $\mathrm{N}$ efflux 


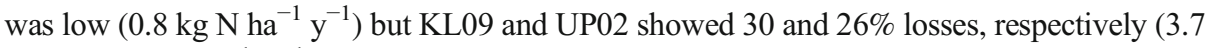
and $4.7 \mathrm{~kg} \mathrm{~N} \mathrm{ha}^{-1} \mathrm{y}^{-1}$ ) (Table 2, S2 F1). N fluxes between 1990 and 2010 were different between the sites (Kruskal-Wallis $X^{2}=39.4-52.5$, $\mathrm{df}=2, p<0.001$ ).

Among the two sites with acidic soils and low base saturation $\mathrm{N}$ stored in trees was twofold in MO11 than in MU16. Mineral soil N and humus N were similar (Table 2). Simulated N leaching loss was 4.9 and $1.3 \mathrm{~kg} \mathrm{~N} \mathrm{ha}^{-1} \mathrm{y}^{-1}$ at MO11 and MU16, respectively, amounting to $31 \%$ of the $\mathrm{N}$ deposition at both sites. Simulated gaseous $\mathrm{N}$ losses were $0.9 \mathrm{~kg} \mathrm{~N}^{-1} \mathrm{y}^{-1}$ at MO11 and 1.4 $\mathrm{kg} \mathrm{N} \mathrm{ha}^{-1} \mathrm{y}^{-1}$ at MU16 (MO11: 6\%, MU16: 33\% of $\mathrm{N}$ deposition) (Table 2, S2 F1). N fluxes between 1990 and 2010 were different between the sites (Kruskal-Wallis $X^{2}=22.2-29.3$, df $\left.=1, p<0.001\right)$.

\subsection{Long-term changes in climatic conditions, $\mathrm{N}$ deposition, and SOM N pools}

Mean annual temperature increased by $1.7-4.3{ }^{\circ} \mathrm{C}$ between $1990-2010$ and $2080-2100$ (S1 T1). Temperature increase was lowest in the $\mathrm{B} 1$ and highest in the $\mathrm{A} 2$ scenarios. Precipitation in the climate scenarios of the sites tended to decrease (by up to $-192 \mathrm{~mm} \mathrm{y}^{-1}$ ) but varied considerably between sites and scenarios. The scenarios A2 (ECHAM5) and A1B (HADCM3) showed the strongest decrease while at some sites precipitation even increased, particularly under the B1 scenario (S1 T1). In 2080-2100, simulated mean annual deposition was 5.4 and $3.2 \mathrm{~kg} \mathrm{~N} \mathrm{ha}^{-1}$ lower than for the period 1990-2010 in the MFR and the CLE scenario, respectively (S1 T1).

Simulated mean annual total SOM N budgets between 2010 and 2100 were predominantly negative (S3 F1). Simulated total SOM N decreased less in JO16, MG15 and UP02 (from -0.6 to $-1.3 \mathrm{~kg} \mathrm{~N} \mathrm{ha}^{-1} \mathrm{y}^{-1}$ ) than in ZB00, AK22, MU16 and MO11 (from -2.1 to $-2.7 \mathrm{~kg} \mathrm{~N} \mathrm{ha}^{-1} \mathrm{y}^{-1}$ ) (Wilcox rank sum test for differences from zero, $p<0.001$ ). At KL09, total SOM N increased in the CLE scenario $\left(+0.5 \mathrm{~kg} \mathrm{~N} \mathrm{ha}^{-1} \mathrm{y}^{-1}\right.$, Wilcox $\left.p<0.001\right)$ decreased in the MFR scenario $\left(-0.2 \mathrm{~kg} \mathrm{~N} \mathrm{ha}^{-1} \mathrm{y}^{-1}\right.$, Wilcox $\left.p<0.001\right)$ but showed no significant trend in the B10 scenario (Wilcox $p=0.131$ ). At UP02, total SOM $\mathrm{N}$ had no trend in the MFR scenario (Wilcox $p=0.128$ ). At all sites changes in total SOM N were dominated by changes in mineral soil $\mathrm{N}$, ranging from -0.1 to $-2.8 \mathrm{~kg} \mathrm{~N} \mathrm{ha}^{-1} \mathrm{y}^{-1}$ (Wilcox $p<0.001$ ).

Table 2 Simulated soil organic matter $\mathrm{N}$ pools in in the humus and the mineral soil, $\mathrm{N}$ in plant biomass, annual $\mathrm{N}$ leaching and gaseous $\mathrm{N}$ efflux between 1990 and 2010 (mean $\pm \mathrm{SEM}$ ). $\mathrm{N}$ loss is the percentage of $\mathrm{N}$ deposition lost to $\mathrm{N}$ leaching and gaseous $\mathrm{N}$ efflux

\begin{tabular}{|c|c|c|c|c|c|c|c|}
\hline & Site & $\begin{array}{l}\text { Humus } \\
\left(\mathrm{kg} \mathrm{N} \mathrm{ha}^{-1}\right)\end{array}$ & $\begin{array}{l}\text { Mineral } \\
\text { soil } \\
\left(\mathrm{kg} \mathrm{N} \mathrm{ha}^{-1}\right)\end{array}$ & $\begin{array}{l}\text { Plant } \\
\left(\mathrm{kg} \mathrm{N} \mathrm{ha}^{-1}\right)\end{array}$ & $\begin{array}{l}\text { Leaching }^{\mathrm{a}} \\
\left(\mathrm{kg} \mathrm{N} \mathrm{ha}{ }^{-1} \mathrm{y}^{-1}\right)\end{array}$ & $\begin{array}{l}\text { Gas efflux }^{\mathrm{a}} \\
\left(\mathrm{kg} \mathrm{N} \mathrm{ha}^{-1} \mathrm{y}^{-1}\right)\end{array}$ & $\begin{array}{l}\mathrm{N} \\
\text { loss } \\
(\%)\end{array}$ \\
\hline \multirow{3}{*}{$\begin{array}{l}\text { Carbonate, } \\
\text { high base } \\
\text { saturation }\end{array}$} & AK22 & $546 \pm 2$ & $22,779 \pm 1$ & $293 \pm 9$ & $3.6 \pm 0.8$ & $1.4 \pm 0.05$ & 32 \\
\hline & MG15 & $148 \pm 4$ & $8638 \pm 2$ & $228 \pm 7$ & $1.0 \pm 0.2$ & $3.7 \pm 0.3$ & 50 \\
\hline & ZB00 & $328 \pm 2$ & $8226 \pm 3$ & $433 \pm 11$ & $15.1 \pm 1.4$ & $3.8 \pm 0.2$ & 68 \\
\hline \multirow{3}{*}{$\begin{array}{l}\text { Acid soil, } \\
\text { high base } \\
\text { saturation }\end{array}$} & JO17 & $299 \pm 1$ & $6761 \pm 2$ & $183 \pm 6$ & $0.1 \pm 0.01$ & $0.8 \pm 0.02$ & 14 \\
\hline & KL09 & $165 \pm 3$ & $8821 \pm 3$ & $317 \pm 9$ & $0.1 \pm 0.01$ & $3.7 \pm 0.2$ & 30 \\
\hline & UP02 & $199 \pm 1$ & $6405 \pm 2$ & $245 \pm 8$ & $5.6 \pm 0.9$ & $4.7 \pm 0.4$ & 58 \\
\hline \multirow{2}{*}{$\begin{array}{l}\text { Acid soil, } \\
\text { low base } \\
\text { saturation }\end{array}$} & MO11 & $417 \pm 2$ & $13,076 \pm 2$ & $429 \pm 11$ & $4.9 \pm 0.6$ & $0.9 \pm 0.03$ & 36 \\
\hline & MU16 & $371 \pm 3$ & $15,878 \pm 1$ & $216 \pm 5$ & $1.3 \pm 0.1$ & $1.4 \pm 0.1$ & 64 \\
\hline
\end{tabular}

${ }^{\mathrm{a}} \mathrm{N}$ fluxes are different between the sites in each of the groups (Kruskal-Wallis $p<0.001$ ) 


\subsection{Climate and $\mathbf{N}$ deposition effects on $\mathbf{N}$ fates at different forest sites}

Temperature increase significantly affected all $\mathrm{N}$ fates in the carbonate sites (Wilcoxon rank sum test $p<0.05$ ) apart from mineral soil $\mathrm{N}$ at ZB00 and humus $\mathrm{N}$ at MG15. There was a particularly strong effect of temperature on simulated plant $\mathrm{N}$ uptake (AK22, ZB00) and on mineral soil N (AK22, MG15). Gaseous efflux of N decreased in MG15 and increased in AK22 and ZB00 (S2 F1). The two carbonate influenced sites with mull humus (AK22, ZB00) showed pronounced $\mathrm{N}$ deposition effects on $\mathrm{N}$ leaching but small effects on the $\mathrm{N}$ pools (Wilcoxon rank sum test $p<0.1$ ) (S2 F1). There, every additional kilogram $\mathrm{N}$ per hectare per year deposited caused between +0.7 and $+0.9 \mathrm{~kg} \mathrm{~N}$ ha $^{-1}$ higher mean annual $\mathrm{N}$ leaching and $0.1 \mathrm{~kg} \mathrm{~N}$ ha ${ }^{-1}$ additional tree $\mathrm{N}$ uptake. At MG15, changes per each additional kilogram $\mathrm{N}$ per hectare per year were small $\left(+0.12\right.$ and $+0.3 \mathrm{~kg} \mathrm{~N} \mathrm{ha}^{-1} \mathrm{y}^{-1}$ for $\mathrm{N}$ leaching and tree $\mathrm{N}$ uptake, respectively) but gaseous $\mathrm{N}$ loss and total SOM N increase was substantially higher $(+0.35$ and $+0.2 \mathrm{~kg} \mathrm{~N} \mathrm{ha}^{-1} \mathrm{y}^{-1}$ ) as compared to the other two sites. At AK22 and ZB00, every degree Celsius warming decreased mean annual $\mathrm{N}$ leaching by -1.2 to $-2 \mathrm{~kg} \mathrm{~N} \mathrm{ha}^{-1}$ and additional tree $\mathrm{N}$ uptake by +0.2 to $+0.5 \mathrm{~kg} \mathrm{~N}$ ha $^{-1}$. Climate change led to higher gaseous $\mathrm{N}$ efflux at these sites. At MG15, annual mean effects on $\mathrm{N}$ fates with every degree Celsius warming were small $\left(<0.17 \mathrm{~kg} \mathrm{~N} \mathrm{ha}^{-1}\right)$ besides gaseous $\mathrm{N}$ loss decreasing by $-0.25 \mathrm{~kg} \mathrm{~N}^{-1}$ which was the highest value among all sites (Fig. 1).

Among the three sites with acidic soils characterised by higher base saturation, KL09 showed very small climate effects on $\mathrm{N}$ fates whereas effects were significant at UP02 and JO17 (Wilcox rank sum $p<0.05$, S2 F1). KL09 and JO17 exerted strong positive effects per $\mathrm{kg} \mathrm{N}$ deposition in tree $\mathrm{N}$ uptake and in total SOM $\mathrm{N}$ being between +0.3 and $+0.4 \mathrm{~kg} \mathrm{~N} \mathrm{ha}^{-1} \mathrm{y}^{-1}$, respectively (Wilcox rank sum $p<0.05$, S2 F1). For all three sites mean annual gaseous $\mathrm{N}$ loss was between +0.1 and $+0.3 \mathrm{~kg} \mathrm{~N}^{-1}$ higher with every $\mathrm{kg} \mathrm{N}$. UP02 was specific as to its lower effect in tree $\mathrm{N}$ uptake but higher effects in mean annual $\mathrm{N}$ leaching $\left(+0.4 \mathrm{~kg} \mathrm{~N} \mathrm{ha}^{-1}\right)$. Warming effects on mean annual tree $\mathrm{N}$ uptake were either low (UP02, JO17, $<0.09 \mathrm{~kg} \mathrm{~N} \mathrm{ha}^{-1}$ ) or even negative (KL09). Whereas JO17 showed no substantial temperature effects, at UP02 and KL09 every degree Celsius warming caused mean annual N leaching and $\mathrm{N}$ gas efflux to decrease by -0.2 to -0.6 and by $-0.2 \mathrm{~kg} \mathrm{~N}^{-1}$, respectively (Fig. 1).

The two sites with acid soils and with low base saturation experienced different $\mathrm{N}$ deposition and corresponding effects. At MU16, the difference between the deposition scenarios was marginal so that all effects on $\mathrm{N}$ fates but on plant $\mathrm{N}$ uptake were insignificant (Wilcox rank sum test $p>0.05, \mathrm{~S} 2 \mathrm{~F} 1$ ). At $\mathrm{MO}$, the deposited $\mathrm{N}$ led to significantly higher uptake of $\mathrm{N}$ in plants and SOM, and higher $\mathrm{N}$ effluxes (Wilcox rank sum test $p>0.05$ ). Mean annual $\mathrm{N}$ leaching was $+0.6 \mathrm{~kg} \mathrm{~N}^{-1}$ higher and mean annual tree $\mathrm{N}$ uptake was $+0.2 \mathrm{~kg} \mathrm{~N} \mathrm{ha}^{-1}$ higher per kilogram $\mathrm{N}$ deposition. The strongest climate change effect was on $\mathrm{N}$ leaching. Every degree Celsius warming decreased $\mathrm{N}$ leaching by between -0.3 and $-0.6 \mathrm{~kg} \mathrm{~N} h a^{-1} \mathrm{y}^{-1}$ and increased tree $\mathrm{N}$ uptake by +0.1 and $+0.2 \mathrm{~kg} \mathrm{~N}^{-1} \mathrm{y}^{-1}$ in MU16 and MO11, respectively (Fig. 1).

\subsection{Drivers of future changes in $\mathbf{N}$ fates}

The post hoc multi-comparison Nemeneyi test showed that effects on $\mathrm{N}$ fates were site dependent (Fig. 1). We found that per kilogram effects of future $\mathrm{N}$ deposition on tree $\mathrm{N}$ uptake were significantly related with the mean annual $\mathrm{N}$ deposition between 
$+1{ }^{\circ} \mathrm{C}$ Climate Warming
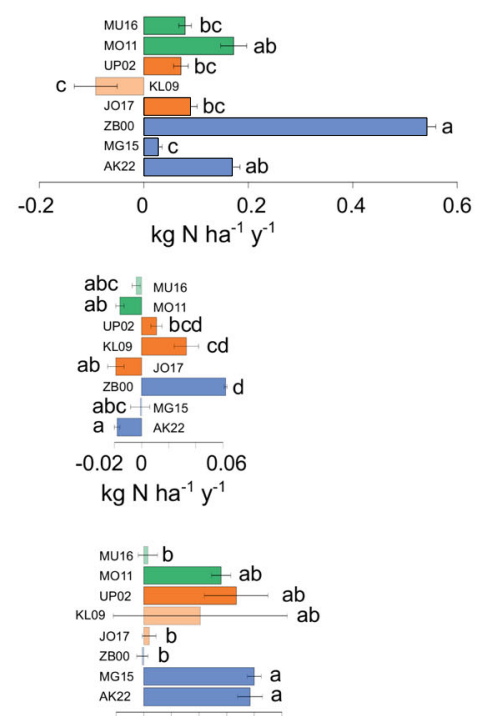

$\begin{array}{llll}-0.02 & 0 & 0.04 & 0.06\end{array}$ $\mathrm{kg} \mathrm{N} \mathrm{ha}^{-1} \mathrm{y}^{-1}$
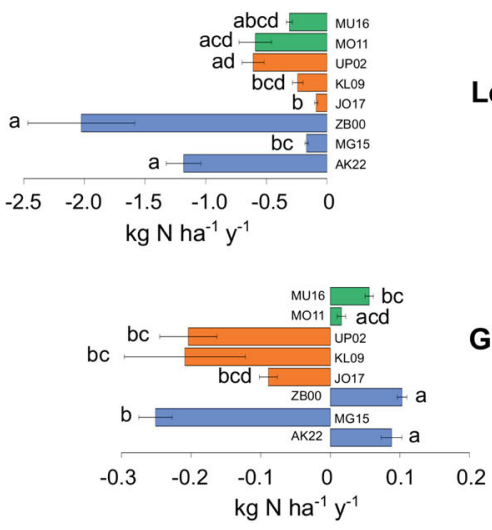

Carbonate, high base saturation

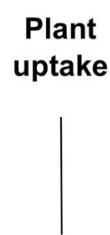

\section{SOM}

humus

layer

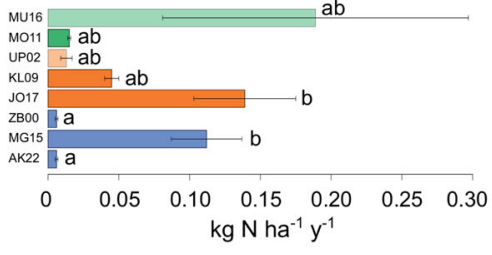

\section{SOM mineral soil}

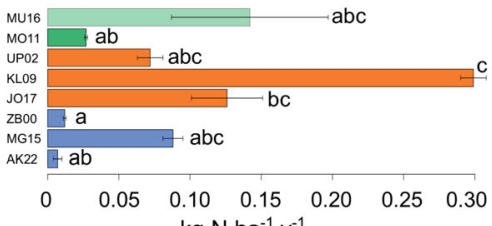
kg N ha ${ }^{-1} \mathrm{y}^{-1}$

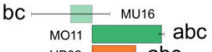

UP02 - abc

KLo9 $\rightarrow$ bc

$\mathrm{JO} 17+\mathrm{C}$

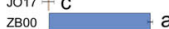

MG15 abc

$$
\begin{aligned}
& \text { MG15 } \\
& \text { AK22 }
\end{aligned}
$$

$\begin{array}{llll}-0.5 & 0 & 0.5 & 1.0\end{array}$ kg N ha ${ }^{-1} y^{-1}$

\section{Gaseous}

loss

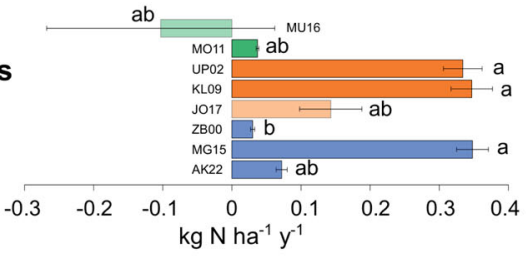

Acidic soils, moder-mull high base saturation
Acidic soils, moder low base saturation

Fig. 1 Effects of $1{ }^{\circ} \mathrm{C}$ warming in annual mean temperature and $1 \mathrm{~kg} \mathrm{~N} \mathrm{ha}^{-1}$ increase in annual deposition rates on $\mathrm{N}$ pools and $\mathrm{N}$ fluxes. Effects are shown as mean annual increases or decreases (plus SEM) in the period between 2080 and 2100 in the $\mathrm{N}$ uptake by plants, SOM N pool, $\mathrm{N}$ leaching with seepage water, and $\mathrm{N}$ loss in gaseous forms. Dark colour bars significantly different effects from zero (Wilcox rank sum test $p<0.05$ ). Letters $a-d$ differences between sites (post hoc multi-comparison Nemeneyi test $p<0.05$ )

1990 and 2010 (Fig. 2a, $R^{2}=0.52, p=0.044$ ) and future gaseous $\mathrm{N}$ emissions with mean annual precipitation between 1990 and 2010 (Fig. $2 b, R^{2}=0.7, p=0.009$ ). 

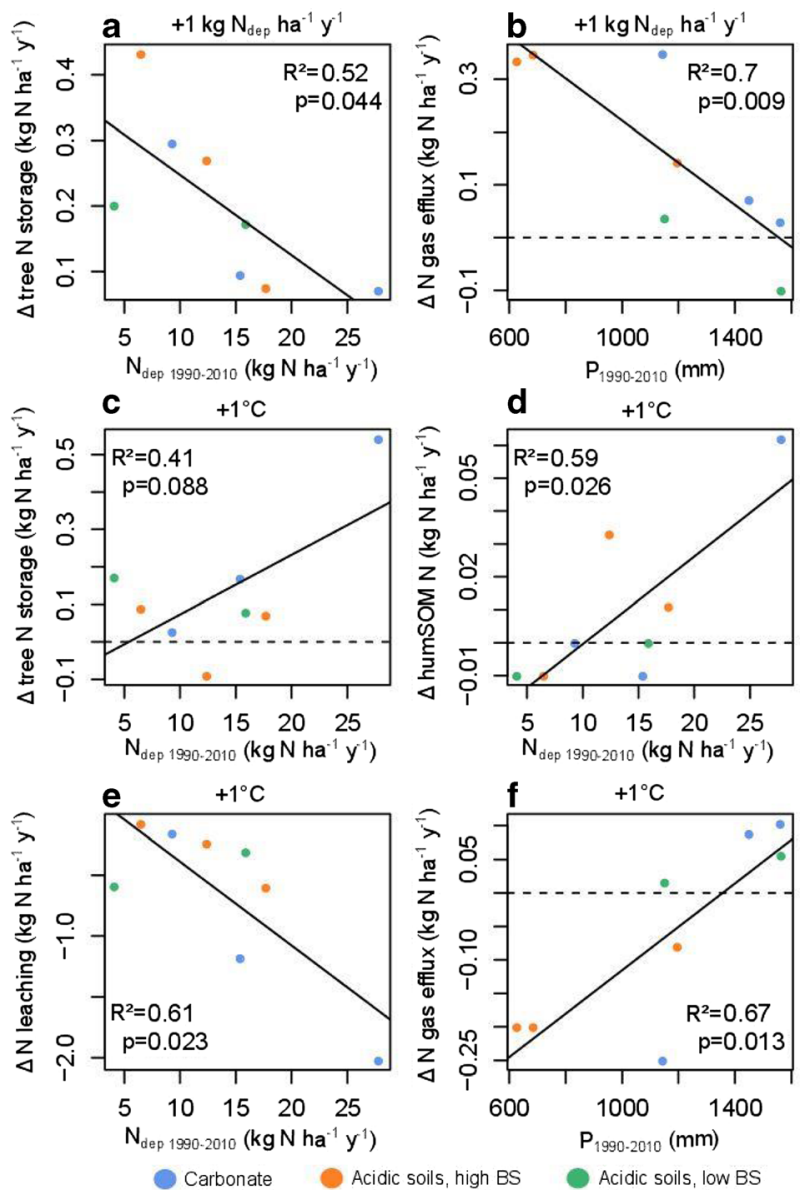

Fig. 2 Relationships between mean $\mathrm{N}$ deposition and precipitation $(\mathrm{P})$ in the period 1990 to 2010 and effects of future $\mathrm{N}$ deposition and climate change on $\mathrm{N}$ fates in the eight study sites. Shown are mean annual effects in the period between 2080 and 2100 in climate and $\mathrm{N}$ deposition scenarios on $\mathrm{N}$ fates per kilogram $\mathrm{N}$ per hectare additional $\mathrm{N}$ deposition (a, b) and per $1{ }^{\circ} \mathrm{C}$ warming (c-f). Dashed horizontal line no effect, positive values increasing pools and flux rates, and negative values decreasing pools and flux rates

In addition, per degree Celsius effects of climate warming on humus $\mathrm{N}$ and $\mathrm{N}$ leaching were significantly related with the mean annual $\mathrm{N}$ deposition between 1990 and 2010 (Fig. 2d-e, $R^{2}=0.59-0.61, p=0.023-0.026$ ). Also tree $\mathrm{N}$ uptake was, though not significantly, higher in sites with high historic $\mathrm{N}$ deposition (Fig. $2 \mathrm{c}, R^{2}=0.41, p=0.088$ ). None of the other site conditions $(\mathrm{T}$, soil $\mathrm{pH}$, soil $\mathrm{C}: \mathrm{N})$ had a significant $(p<0.05)$ relation with standardized future effects of $\mathrm{N}$ depositions or climate change.

\section{Discussion}

The magnitude of $\mathrm{N}$ deposition between 1990 and 2010 was by far the most significant determinant of future warming effects on forest ecosystem $\mathrm{N}$ retention explaining $59-61 \%$ of 
the variation in $\mathrm{N}$ leaching and humus $\mathrm{N}$ changes. Hence, climate warming caused higher SOM N storage and lower $\mathrm{N}$ leaching in sites where $\mathrm{N}$ deposition was high in the past compared to sites where it was low. Those sites experiencing water shortage in future were an exception because soil water limitations inhibited tree $\mathrm{N}$ uptake and SOM decomposition while continuously high $\mathrm{N}$ deposition caused higher $\mathrm{N}$ accumulation in SOM, increased $\mathrm{N}$ leaching and gaseous $\mathrm{N}$ losses.

We could show that LandscapeDNDC was capable of modelling soil water dynamics and forest growth of the investigated sites and the resulting $\mathrm{N}$ budgets were in line with measurements (see details in S4). Nevertheless, not all factors have been taken into account. Particularly, we neglected future increase in atmospheric $\mathrm{CO}_{2}$ concentration despite its effect on N mineralization and biomass (Reich and Hobbie 2013).

In most sites higher rates of $\mathrm{N}$ deposition caused significantly higher tree growth and related uptake of $\mathrm{N}$ in plant biomass, which was accompanied by higher rates of $\mathrm{N}$ mineralization and nitrification in soils. We found a significant mean annual increase of +0.07 to $+0.43 \mathrm{~kg} \mathrm{~N} \mathrm{ha}^{-1} \mathrm{y}^{-1}$ in plant biomass with every additional kilogram $\mathrm{N}$ input via atmospheric $\mathrm{N}$ deposition. This corresponds to a mean annual biomass increase of approximately $50-150 \mathrm{~kg} \mathrm{ha}^{-1}$ when using mean $\mathrm{N}$ concentration of $2.8 \mathrm{~g} \mathrm{~N} \mathrm{~kg}^{-1}$ (Jacobsen et al. 2002). By the end of the twenty-first century the forest stands would have 5-15\% more biomass under the B10 deposition than the MFR deposition scenario. This result corresponds quite well with estimated $1 \%$ growth increase with every kilogram $\mathrm{N}$ per hectare as in Laubhann et al. (2009) and Solberg et al. (2009). We can neglect any age-dependent difference in $\mathrm{N}$ uptake between sites because all model runs were initiated in the year 1950 and forests reached maturity by the end of the model runs. Nevertheless, future $\mathrm{N}$ deposition did not result in the same relative changes in tree growth among sites. In the three sites with the highest $\mathrm{N}$ deposition between 1990 and 2010 (AK22, UP02, ZB00) uptake increased by only +0.07 to $+0.1 \mathrm{~kg} \mathrm{~N}^{-1}$ per $1 \mathrm{~kg} \mathrm{~N}^{-1}$ haposition while in sites with low historic deposition (MG15, JO17) tree $\mathrm{N}$ uptake increased by +0.3 to $+0.4 \mathrm{~kg} \mathrm{~N} \mathrm{ha}{ }^{-1}$ per $1 \mathrm{~kg} \mathrm{~N} h a^{-1}$ deposition. This is in line with empirical evidence showing that chronic $\mathrm{N}$ deposition stimulates tree growth only to a certain level (de Vries et al. 2014) and may even be adverse at high levels of $\mathrm{N}$ deposition (Magill et al. 2004).

Significant retention of additional $\mathrm{N}$ in $\mathrm{SOM}$ occurred together with tree $\mathrm{N}$ uptake and was between +0.02 and $+0.3 \mathrm{~kg} \mathrm{~N}^{-1} \mathrm{y}^{-1}$ with every additional kilogram $\mathrm{N}$ per hectare in deposition. This results in a ratio of approx. 3:2 between plant and soil $\mathrm{N}$ retention and corroborates well with ecosystem partitioning of $\mathrm{C}$ sequestration with $\mathrm{N}$ deposition (De Vries et al. 2014). It is notable that some processes responsible for soil $\mathrm{N}$ retention are not fully captured by the model. Kaiser et al. (2010) demonstrated efficient $\mathrm{N}$ retention processes for KL09 by seasonal switches in soil microbial communities preferably feeding on soil organic matter in summer and on plant litter in autumn. Hence, we may have underestimated whole year soil $\mathrm{N}$ retention to some extent. In contrast to tree $\mathrm{N}$ uptake, we did not find a relation between historic $\mathrm{N}$ deposition and future $\mathrm{N}$ deposition effects on SOM $\mathrm{N}$ retention which might be controlled by a combination of factors which we cannot test because of the small number of sites. As an example, at sites where low $\mathrm{C}: \mathrm{N}$ ratios of 17 were combined with mull type humus and high soil $\mathrm{pH}$ (AK22, ZB00), SOM N retention was particularly limited, as was also shown in Brumme and Khanna (2008), and much 
lower than at the third site on carbonate bedrock (MG11) characterized with a much higher A-horizon $\mathrm{C}: \mathrm{N}$ ratio of 25. However, SOM N retention at MG11 was similar to sites such as JO17 and KL09 which are characterised by even lower C:N ratios (13-14) than AK22 and ZB00. At ZB00 and AK22, high precipitation and coarse textured soils cause high percolation and leaching losses (Jandl et al. 2012; Jost et al. 2011), contributing to the variation in $\mathrm{N}$ retention between these and other sites.

Long-term mean annual precipitation explained $70 \%$ of the variation in effects of $\mathrm{N}$ deposition on future gaseous $\mathrm{N}$ effluxes, which were predominantly positive. Simulated gaseous $\mathrm{N}$ efflux was particularly sensible to $\mathrm{N}$ deposition at the two driest study sites (KL09, UP02) but also at MG15. Both, tree $\mathrm{N}$ uptake and $\mathrm{N}$ immobilization in SOM are low in the dry sites due to chronic $\mathrm{N}$ deposition. $\mathrm{N}$ leaching is low because of low percolation, hence leaving disproportional amounts of $\mathrm{N}$ being prone to gaseous efflux. Higher bulk densities at these two sites, leading to lower porosity and thus generally higher anaerobic volume fractions causing denitrification, might explain the sensitivity of gaseous $\mathrm{N}$ loss to $\mathrm{N}$ deposition (Butterbach-Bahl et al. 2013).

Similar to $\mathrm{N}$ deposition, we found significantly increased tree $\mathrm{N}$ uptake with expected future climate change. The impact of climate warming on the increase in temperate forest tree growth over the last decades is well documented (Laubhann et al. 2009; Pretzsch et al. 2014a; Pretzsch et al. 2014b; Solberg et al. 2009; Thomas et al. 2010). Mean annual future rates of tree $\mathrm{N}$ uptake caused by each ${ }^{\circ} \mathrm{C}$ warming were between +0.03 to $+0.5 \mathrm{~kg} \mathrm{~N}^{-1} \mathrm{y}^{-1}$. $\mathrm{N}$ deposition between 1990 and 2010 explained $41 \%$ of this variation showing that future warming induced tree growth might be higher in sites with high $\mathrm{N}$ deposition in the past. Though this relationship was only marginally significant $(p=0.088)$ and strongly controlled by only one site (ZB00) tree fertilization due to enhanced $\mathrm{N}$ mineralization rates under warming has been shown experimentally (Butler et al. 2012), and it is likely that the stimulation of tree growth is higher in sites with low $\mathrm{N}$ limitation as a result of higher $\mathrm{N}$ loads in the past. $\mathrm{N}$ deposition during the period 1990-2010 also controlled future $\mathrm{N}$ retention in humus. Reduced organic matter decomposition due to $\mathrm{N}$ deposition as shown in Frey et al. (2014) together with higher litter input may add to the increased SOM N retention. Hence, future climate change increases $\mathrm{N}$ retention particularly in sites in an advanced state of $\mathrm{N}$ saturation, which would otherwise lose $\mathrm{N}$ in gaseous form or as nitrate via seepage water. Indeed, past $\mathrm{N}$ deposition explained $61 \%$ of the variation in the future $\mathrm{N}$ leaching decrease across sites caused by warming.

Relative to the climate effects on plant $\mathrm{N}$ uptake, SOM $\mathrm{N}$ retention and leaching, the effects on gaseous $\mathrm{N}$ loss were small and idiosyncratic. Depending upon the annual sum of precipitation, $\mathrm{N}$ efflux was either positively or negatively affected. Future climate warming led to decreasing $\mathrm{N}$ gas efflux but only in the driest sites, which might be related to a decrease in rates of denitrification due to evapotranspiration. Mean annual precipitation in fact was a good predictor for the variation in gaseous $\mathrm{N}$ efflux effects of warming $\left(R^{2}=0.67, p=0.017\right)$. This agrees well with findings at one of the study sites characterised by high precipitation (AK22). Experimental soil warming by $4{ }^{\circ} \mathrm{C}$ in the growing season led to persistently elevated annual $\mathrm{N}_{2} \mathrm{O}$ emissions (Gundersen et al. 2006) which may have been related to higher microbial activity as mineral nitrogen concentrations did not increase at the warmed plots (Schindlbacher et al. 2009). Hence, these observations corroborate our findings at the humid sites, but require 
caution because changes in $\mathrm{N}_{2} \mathrm{O}$ emissions do not necessarily reflect changes in total $\mathrm{N}$ gas efflux.

\section{Conclusions}

Our study indicates that while $\mathrm{N}$ deposition weakens $\mathrm{N}$ retention in Austrian temperate forest ecosystems, expected future climate change will likely have a strong offsetting effect by increasing $\mathrm{N}$ immobilization in tree biomass and SOM. However, the future magnitude of this compensation will be strongly site dependent. We identified magnitude of historic $\mathrm{N}$ deposition to be most important but could also show climatic constraints with sites of low annual precipitation being less affected when becoming drier in future. Anticipated reduction in $\mathrm{N}$ deposition under a current legislation scenario will additionally lower $\mathrm{N}$ availability in these forest ecosystems very likely causing a lower net $\mathrm{N}$ loss to the atmosphere and the groundwater than we measure today.

Acknowledgements The study was funded by the Austrian Climate Research Program (ACRP5 - CCN-Adapt KR12AC5K01308). D.T., K.R. and H.E. received additional funding from the European Union's Horizon 2020 research and innovation programme (grant agreement no. 6417, ECOPOTENTIAL). We are grateful to the data providers of the UNECE-CLRTAP International Cooperation Programs ICP Forests, ICP Integrated Monitoring, and the Coordination Centre of Effects. D.T. acknowledges the support provided by Pamela Templer and her comments on an earlier version of the manuscript.

Open Access This article is distributed under the terms of the Creative Commons Attribution 4.0 International License (http://creativecommons.org/licenses/by/4.0/), which permits unrestricted use, distribution, and reproduction in any medium, provided you give appropriate credit to the original author(s) and the source, provide a link to the Creative Commons license, and indicate if changes were made.

\section{References}

Aber JD et al (1998) Nitrogen saturation in temperate forest ecosystems: hypotheses revisited. Bio Science 48: 921-934

Aber JD et al (2003) Is nitrogen deposition altering the nitrogen status of northeastern forests? Bio Science 53: 375-389. doi:10.1641/0006-3568(2003)053\%5B0375:indatn\%5D2.0.co

Brumme R, Borken W, Finke S (1999) Hierarchical control on nitrous oxide emission in forest ecosystems. Glob Biogeochem Cycles 13:1137-1148. doi:10.1029/1999gb900017

Brumme R, Khanna PK (2008) Ecological and site historical aspects of N dynamics and current N status in temperate forests. Glob Chang Biol 14:125-141

Butler SM et al (2012) Soil warming alters nitrogen cycling in a New England forest: implications for ecosystem function and structure. Oecologia 168:819-828. doi:10.1007/s00442-011-2133-7

Butterbach-Bahl K, Baggs EM, Dannenmann M, Kiese R, Zechmeister-Boltenstern S (2013) Nitrous oxide emissions from soils: how well do we understand the processes and their controls? Philosophical Transactions of the Royal Society B: Biological Sciences 368. doi:10.1098/rstb.2013.0122

Butterbach-Bahl K, Gundersen P (2011) Nitrogen processes in terrestrial ecosystems. In: Sutton MA et al. (eds) The European Nitrogen Assessment. Cambridge University Press, pp 99-124

Butterbach-Bahl K, Rothe A, Papen $\mathrm{H}$ (2002) Effect of tree distance on $\mathrm{N}_{2} \mathrm{O}$ and $\mathrm{CH}_{4}$-fluxes from soils in temperate forest ecosystems. Plant Soil 240:91-103. doi:10.1023/a:1015828701885

Charru M, Seynave I, Hervé J-C, Bontemps J-D (2014) Spatial patterns of historical growth changes in Norway spruce across western European mountains and the key effect of climate warming. Trees 28:205-221. doi: 10.1007/s00468-013-0943-4

Dannenmann M, Gasche R, Papen $\mathrm{H}$ (2007) Nitrogen turnover and $\mathrm{N}_{2} \mathrm{O}$ production in the forest floor of beech stands as influenced by forest management. J Plant Nutr Soil Sci 170:134-144. doi:10.1002/jpln.200620644 
Davidson EA, Janssens IA (2006) Temperature sensitivity of soil carbon decomposition and feedbacks to climate change. Nature 440:165-173

De Vries W, Du E, Butterbach-Bahl K (2014) Short and long-term impacts of nitrogen deposition on carbon sequestration by forest ecosystems. Curr Opin Environ Sustain 9-10:90-104. doi:10.1016/j.cosust.2014.09. 001

Dirnböck T et al (2014) Forest floor vegetation response to nitrogen deposition in Europe. Glob Chang Biol 20: 429-440. doi:10.1111/gcb. 12440

Dirnböck T, Kobler J, Kraus D, Grote R, Kiese R (2016) Impacts of management and climate change on nitrate leaching in a forested karst area. J Environ Manag 165:243-252. doi:10.1016/j.jenvman.2015.09.039

Fang J et al (2014) Evidence for environmentally enhanced forest growth. Proc Natl Acad Sci 111:9527-9532. doi:10.1073/pnas.1402333111

Frey SD et al (2014) Chronic nitrogen additions suppress decomposition and sequester soil carbon in temperate forests. Biogeochemistry 121:305-316. doi:10.1007/s10533-014-0004-0

Grote R, Kiese R, Grünwald T, Ourcival J-M, Granier A (2011a) Modelling forest carbon balances considering tree mortality and removal. Agric For Meteorol 151:179-190. doi:10.1016/j.agrformet.2010.10.002

Grote R, Korhonen J, Mammarella I (2011b) Challenges for evaluating process-based models of gas exchange. Forest Systems 20:389-406. doi:10.5424/fs/20112003-11084

Grote R, Lehmann E, Brümmer C, Brüggemann N, Szarzynski J, Kunstmann H (2009) Modelling and observation of biosphere-atmosphere interactions in natural savannah in Burkina Faso, West Africa. Physics and Chemistry of the Earth, Parts A/B/C 34:251-260. doi:10.1016/j.pce.2008.05.003

Gundersen P, Schmidt IK, Raulund-Rasmussen K (2006) Leaching of nitrate from temperate forests — effects of air pollution and forest management. Environ Rev 14:1-57

Haas E et al (2013) LandscapeDNDC: a process model for simulation of biosphere-atmosphere-hydrosphere exchange processes at site and regional scale. Landsc Ecol 28:615-636. doi:10.1007/s10980-012-9772-x

Holst J, Grote R, Offermann C, Ferrio J, Gessler A, Mayer H, Rennenberg H (2010) Water fluxes within beech stands in complex terrain. Int J Biometeorol 54:23-36. doi:10.1007/s00484-009-0248-x

IPCC AR4 WG1 (2007) Climate change 2007: the physical science basis, contribution of working group I to the fourth assessment report of the intergovernmental panel on climate change. Cambridge, United Kingdom and New York

Jacobsen C, Rademacher P, Meesenburg H, Meiwes KJ (2002) Gehalte chemischer Elemente in den Baumkompartimenten - Literaturstudie und Datensammlung. Forschungszentrums Waldökosysteme der Universität Göttingen, Göttingen

Jandl R et al (2012) The carbon and nitrogen biogeochemistry of a montane Norway spruce (Picea abies (L.) Karst.) forest: a synthesis of long-term research. Plant Ecology \& Diversity 5:105-114. doi:10.1080/ 17550874.2012.695813

Jonard M et al (2015) Tree mineral nutrition is deteriorating in Europe. Glob Chang Biol 21:418-430. doi:10. $1111 /$ gcb.12657

Jost G, Dirnböck T, Grabner M-T, Mirtl M (2011) Nitrogen leaching of two forest ecosystems in a karst watershed. Water Air Soil Pollut 218:633-649. doi:10.1007/s11270-010-0674-8

Kaiser C et al (2010) Belowground carbon allocation by trees drives seasonal patterns of extracellular enzyme activities by altering microbial community composition in a beech forest soil. New Phytol 187:843-858. doi:10.1111/j.1469-8137.2010.03321.x

Laubhann D, Sterba H, Reinds GJ, De Vries W (2009) The impact of atmospheric deposition and climate on forest growth in European monitoring plots: an individual tree growth model. For Ecol Manag 258:1751-1761. doi: 10.1016/j.foreco.2008.09.050

Li C, Aber J, Stange F, Butterbach-Bahl K, Papen H (2000) A process-oriented model of $\mathrm{N}_{2} \mathrm{O}$ and NO emissions from forest soils: 1. Model development. Journal of Geophysical Research: Atmospheres 105:4369-4384. doi:10.1029/1999jd900949

Li C, Frolking S, Frolking TA (1992) A model of nitrous oxide evolution from soil driven by rainfall events: 1. Model structure and sensitivity. Journal of Geophysical Research: Atmospheres 97:9759-9776. doi:10.1029/ $92 \mathrm{jd} 00509$

Loibl W, Formayer H, Schöner W, Truhetz H, Anders I, Gobiet A, Heinrich G, Köstl M, Nadeem I, PetersAnders J, Schicker I, Suklitsch M, Züger H (2011) Reclip:century 1: Models, data and GHG-Scenarios, simulations. AIT Austrian Institute of Technology, Vienna

Lovett GM, Goodale CL (2011) A new conceptual model of nitrogen saturation based on experimental nitrogen addition to an oak forest. Ecosystems 14:615-631. doi:10.1007/s10021-011-9432-Z

Magill AH et al (2004) Ecosystem response to 15 years of chronic nitrogen additions at the Harvard Forest LTER. Massachusetts, USA Forest Ecology and Management 196:7-28

Marschall J (2011) Hilfstafeln für die Forsteinrichtung., 5 edn. Österreichischer Agrarverlag, Vienna, Austria 
McMahon SM, Parker GG, Miller DR (2010) Evidence for a recent increase in forest growth. Proc Natl Acad Sci 107:3611-3615. doi:10.1073/pnas.0912376107

Molina-Herrera S et al (2015) Simulation of $\mathrm{CO}_{2}$ fluxes in European forest ecosystems with the coupled soilvegetation process model "LandscapeDNDC". Forests 6:1779

Mutsch F et al. (2013) Projekt BioSoil - Europäisches Waldboden-Monitoring (2006/07) Datenband Österreich. vol 1 and 2. BFW Berichte, vol 145. Vienna

Pohlert T (2014) The Pairwise Multiple Comparison of Mean Ranks Package (PMCMR). R package

Porter EM, Bowman WD, Clark CM, Compton JE, Pardo LH, Soong JL (2013) Interactive effects of anthropogenic nitrogen enrichment and climate change on terrestrial and aquatic biodiversity. Biogeochemistry 114 : 93-120. doi:10.1007/s10533-012-9803-3

Pretzsch H, Biber P, Schütze G, Bielak K (2014b) Changes of forest stand dynamics in Europe. Facts from longterm observational plots and their relevance for forest ecology and management. For Ecol Manag 316:65-77. doi:10.1016/j.foreco.2013.07.050

Pretzsch H, Biber P, Schütze G, Uhl E, Rötzer T (2014a) Forest stand growth dynamics in Central Europe have accelerated since 1870. Nat Commun:5. doi:10.1038/ncomms5967

Reich PB, Hobbie SE (2013) Decade-long soil nitrogen constraint on the $\mathrm{CO}_{2}$ fertilization of plant biomass. Nat Clim Chang 3:278-282. doi:10.1038/nclimate1694

Rothe A, Huber C, Kreutzer K, Weis W (2002) Deposition and soil leaching in stands of Norway spruce and European beech: results from the Höglwald research in comparison with other European case studies. Plant Soil 240:33-45

Schindlbacher A, Zechmeister-Boltenstern S, Jandl R (2009) Carbon losses due to soil warming: do autotrophic and heterotrophic soil respiration respond equally? Glob Chang Biol 15:901-913. doi:10.1111/j.1365-2486. 2008.01757.x

Solberg S et al (2009) Analyses of the impact of changes in atmospheric deposition and climate on forest growth in European monitoring plots: a stand growth approach. For Ecol Manag 258:1735-1750. doi:10.1016/j. foreco.2008.09.057

Stöckle CO, Campbell G, Nelson S (1999) ClimGen manual. Biological systems engineering department. Washington State University, Pullman

Templer PH (2013) Biogeochemistry: limits on carbon uptake by plants. Nature Clim Change 3:184-185

Thomas RQ, Canham CD, Weathers KC, Goodale CL (2010) Increased tree carbon storage in response to nitrogen deposition in the US. Nature Geosci 3:13-17. doi:10.1038/ngeo721

Thornley JHM, Cannell MGR (2000) Modelling the components of plant respiration: representation and realism. Ann Bot 85:55-67. doi:10.1006/anbo.1999.0997

van Groenigen JW, Huygens D, Boeckx P, Kuyper TW, Lubbers IM, Rütting T, Groffman PM (2015) The soil N cycle: new insights and key challenges. Soil 1:235-256. doi:10.5194/soil-1-235-2015

Yue K, Peng Y, Peng C, Yang W, Peng X, Wu F (2016) Stimulation of terrestrial ecosystem carbon storage by nitrogen addition: a meta-analysis. Sci Rep 6:19895. doi:10.1038/srep19895 